\title{
ĐÁNH GIÁ KẾT QUẢ TẠO HìNH KHUYẾT HỔNG PHẦN MỀM NGÓN TAY BẰNG VẠT CUỐNG LIỀN TẠI CHỖ
}

\section{TÓM TẮT}

Đắt vấn đề: Vat tại chỗ là phương pháp được lưa chọn đầu tiên để tạo hình các KHPM NT do vạt đáp ứng đây đủ các yêu câu của quá trình tạo hình mà không làm tổn thương thêm ngón tay lành. Đối tượng và phương pháp nghiên cứu: Nghiên cứu can thiêp lâm sàng không đối chứng được tiến hành trên 115 bệnh nhân với 130 khuyết hổng phần mềm ngón tay được tạo hình bằng vạt cuống liền tại chỗ tại khoa phẫu thuật tạo hình thẩm mỹ bệnh viện đa khoa Xanh Pôn và bệnh viện hữu nghị Việt Tiệp Hải Phòng. Kết quả: Trong tổng số 130 vạt khổng có trường hợp nào chảy máu nơi cho và nhận vat, không có hiện tượng nhiễm khuẩn nơi cho vạt có 4/130 ngón tay bị nhiễm khuẩn nơi nhân vạt, có $10 / 130$ vat bi hoai từ một phân dưới $1 / 3$ diện tích, có 22/130 vạt có hiện tượng ứ máu tĩnh mạch tạm thời tại vạt. Kết luận: Không có vạt tại chỗ nào là ưu điểm tuyệt đối trong tạo hình khuyết hổng phần mềm ngón tay.

Từ khóa: Khuyết phần mềm ngón tay, vạt tại chỗ, vạt ngẫu nhiên, vạt trục mạch.

\section{SUMMARY \\ ASSESSMENT OF RECONSTRUCTION \\ RESUTS OF SOFT TISSUE DEFECTS OF \\ FINGERS USING LOCAL PEDICLE FLAP}

Background: Pedicled perforator flap in hand is variety and flexible motion. Purpose: Describing characteristics of soft tissue defects and evaluating results of reconstructing this injuries by local pedicled perforator flaps at Viet Tiep Hospital from 1/2018 to 9/2018. Method: Uncontrolled clinical interventional study. Results: 11 patients with 13 soft tissue defects were treated by 15 local pedicled perforator flaps. The minimum size of flap was $1,5 \times 2 \mathrm{~cm}$ and the maximum one was $3 \times 9 \mathrm{~cm}$. There were 14 flaps which were survived and one flap was necrosis at the one third lower area of flap. 14/15 donor sites were performed thickness skin grafts and they were survived. 1/15 flap was sutured directly to heal by primary intention. Conclusion: Local pedicled perforator flaps are trustful material to reconstruct soft tissue defects of fingers.

Keywords: Finger soft tissue defect, perforator flap, local flap.

\section{I. ĐĂT VẤN ĐỀ}

Bàn tay (BT), đặc biệt là các ngón tay (NT), là bộ phận tinh tế nhất của hệ vận động, tham

\footnotetext{
${ }^{1}$ Trường Đại học Y Dược Hải Phòng

2Bênh viện Trung ương Quân đội 108

Chịu trách nhiệm chính: Nguyễn Đức Tiến

Email: ndtien@hpmu.edu.vn

Ngày nhận bài: 7.5.2021

Ngày phản biên khoa hoc: 25.6.2021

Ngày duyệt bài: 7.7.2021
}

gia vào hâu hết các hoạt động trong lao động và trong sinh hoạt hàng ngày, thực hiện chức năng vận động tinh vi và xúc giác tinh tế. Trong khi đó các chấn thương, vết thương bàn ngón tay là tổn thương khuyết hổng phân mềm (KHPM) ngón tay là tổn thương thường gặp. Tuy vết thương khuyết ổng phân mềm ngón tay ít khi đe dọa tính mạng bênh nhân nhưng nếu điêu trị không đúng sẽ dẫn đến mất chức năng và biến dạng hình thái của ngón tay. Theo Robert $W$. Beasley [1]: Có 3 yếu tố quan trọng khi lựa chọn vạt tổ chức để tạo hình khuyết hổng phẩn mềm ngón tay đó là: Bảo tồn được chức năng xúc giác tinh tế của ngón tay, ít làm tổn hại nơi cho vạt và vạt áp dụng có tính khả thi và tin cậy có thể dự đoán được kết quả phẫu thuât.

Vạt tại chỗ là phương pháp được lựa chọn đâu tiên để tạo hình các KHPM NT do vạt đáp ứng đây đủ các yêu câu của quá trình tạo hình mà không làm tổn thương thêm ngón tay lành. Tuy nhiên một tổn thương có thể được tạo hình bằng nhiêuu phương pháp khác nhau và ngược lại một phương pháp có thể ứng dụng cho một số loại tổn thương. Do đó khi đánh giá kết quả phẫu thuât sẽ giúp đánh giá được ưu nhược điểm của từng loại vạt để đưa ra những gợi ý để lựa chọn loại vạt nào cho phù hợp vừa đảm bảo chức năng nơi nhận mà không làm tổn hại nơi cho. Do đó chúng tôi tiến hành nghiên cứu đề tài này nhằm mục tiêu: "Đánh giá kêt quả tạo hinh khuyêt hổng phần mềm ngón tay bằng vạt cuống liền tại chỗ".

\section{II. ĐỐI TƯỢNG VÀ PHƯƠNG PHÁP NGHIÊN CỨU}

1. Đối tượng nghiên cứu. Nghiên cứu được tiến hành trên 115 BN có vết thương KPHM NT có chỉ định phẫu thuật che phủ KHPM bằng vat cuống liên tai chỗ tại khoa phẫu thuât tao hình thẩm mỹ bệnh viện đa khoa Xanh - Pôn và khoa phẫu thuật tạo hình thẩm mỹ bệnh viện Hữu Nghị Việt Tiệp Hải Phòng từ 10/2016 đến $12 / 2020$

\subsection{Tiêu chuẩn lựa chọn.}

- Bao gồm tất cả các bệnh nhân có tổn thương KHPM NT do các nguyên nhân khác nhau được tạo hình che phủ bằng vạt cuống liên tại chỗ.

- Các BN có KHPM NT sau khi điều trị nhễm trùng đã ổn định.

- Các BN có KHPM NT sau phẫu thuật cắt sẹo 
giải phóng co kéo do di chứng bỏng, di chứng chấn thương...

\subsection{Tiêu chuẩn loai trừ.}

- Bênh nhân có các tổn thương khác kễ hợp tại ngón tay bị khuyết hổng phần mềm: Gãy xương hở, trật khớp, đứt gân.

- Bênhh nhân có khuyết hổng phần mềm ngón tay khổng được tạo hình che phủ bằng vạt mạch xuyên cuống liền tại chỗ.

- Bệnh nhân không đồng ý tham gia nghiên cứu.

\section{Phương pháp nghiên cứu.}

2.1. Địa điểm và thời gian nghiên cứu.

Địa điểm nghiên cứu: Khoa phẫu thuật tạo hình thẩm mỹ bênh viện đa khoa xanh pôn và khoa phẫu thuật tạo hình thẩm mỹ bệnh viện hữu nghị Việt Tiệp Hải Phòng.

Thời gian nghiên cứu: Từ tháng 10/2016 đến tháng 12/2020.

2.2. Thiết kế nghiên cứu: Nghiên cứu can thiệp không đối chứng.

\subsection{Cách chon mẫu}

Chọn mẫu thuật tiện: Lựa chọn tất cả các bệnh nhân đủ tiêu chuẩn lựa chọn trong thời gian nghiên cứu.

\section{4. Đao đức trong nghiên cứu.}

Phẫu thuật che phủ khuyết hổng phần mềm ngón tay bằng các vạt tại chỗ được thực hiện theo đúng quy trình kỹ் thuật Bộ Y tể.

- Tất cả các bệnh nhân được giải thích trước khi tham gia vào nghiên cứu, bệnh nhân có quyên từ chối tham gia vào bất kỳ giai đoạn nào của quá trình nghiên cứu, các bênh nhân đồng ý và không đồng ý tham gia vào nghiên cứu được điều trị theo quy trình của Bộ Y Tế.

- Nghiên cứu được tiến hành theo đúng đề cương nghiên cứu đã được hội đồng đạo đức nghiên cứu $Y$ sinh học trường đại học $Y$ Hà Nội thông qua.

\section{KẾT QUẢ NGHIÊN CứU}

1. Đăc điểm lâm sàng. Qua quá trình nghiên cứu trên 115 BN với 130 KHPM NT được điều trị bằng vạt cuống liền tại chỗ chúng tôi thu được một số kểt quả như sau:

Đặc điểm đối tượng nghiên cứu: Trong nghiển cứu của chúng tôi $B N$ cao tuổi nhất là 76 thấp tuổi nhất là 2 tuổi, trong nhóm tuổi từ 2039 chiếm tỷ lệ cao nhất với $62 \mathrm{BN}$ chiếm tỷ lệ $54 \%$ tiếp theo là $B N$ trong nhóm tuổi từ 40 đến 59 tuổi chiếm $24,3 \%$, ít nhất là bệnh nhân ở nhóm trên 60 tuổi. Trong số $115 \mathrm{BN}$ của chúng tôi có $76 \mathrm{BN}$ nam chiếm tỷ lệ $66,1 \%, 39 \mathrm{BN}$ nữ chiếm tỷ lệ 33,9\%. Nguyên nhân gây VTBT phổ biến nhất là tai nạn lao động (TNLĐ) 72/115 BN chiếm tỷ lệ 64,3\%.
Đặc điểm tổn thương:

Bảng 3.1: Mô tả đặc điểm tổn thương theo đơn vi bàn tay, ngón tay

\begin{tabular}{|c|c|c|c|c|}
\hline \multirow{2}{*}{ Ngón } & \multicolumn{2}{|c|}{ Bàn tay } & \multirow{2}{*}{ Tổng } & \multirow{2}{*}{ P } \\
\cline { 2 - 3 } & Phải & Trái & & \\
\hline 1 & $13(61,9 \%)$ & $8(38,1 \%)$ & $21(16,2 \%)$ & \\
\hline 2 & $21(55,3 \%)$ & $17(44,7 \%)$ & $38(29,4 \%)$ & \\
\hline 3 & $15(40,5 \%)$ & $22(59,5 \%)$ & $37(28,5 \%)$ & \multirow{2}{*}{0,102} \\
\hline 4 & $7(28 \%)$ & $18(72 \%)$ & $25(19,2 \%)$ & \\
\hline 5 & $3(33,3 \%)$ & $6(66,7 \%)$ & $9(6,9 \%)$ & \\
\hline Tổng & $59(45,4 \%)$ & $71(54,6 \%)$ & $130(100 \%)$ & \\
\hline
\end{tabular}

Nhật xét: Theo bảng 3.1 ta thấy: Tỷ lệ bàn tay trái có vết thương khuyết phần mềm ngón tay chiếm tỷ lệ cao hơn bàn tay phải $(54,6 \%$ so với 45,4\%). Tuy nhiên sự khác biệt không có ý nghĩa thống kê với $p=0,102(>0,05)$.

Về phân loại tổn thương theo đơn vị ngón tay thì ngón 2 và ngón 3 hay bị tổn thương nhất $(29,4 \%$ và $28,5 \%)$, ngón ít bị tổn thương nhất là ngón 5 (6,9\%).

2. Kêt quả phẫu thuật. Trong nghiên cứu của chúng tôi vạt nhỏ nhất có kích thước là: 0,5 $\mathrm{cm}^{2}$, vạt có kích thước lớn nhất là $27 \mathrm{~cm}^{2}$, Kích thước trung bình vạt ngẫu nhiên lớn hơn vạt trục mạch, vạt xuôi dòng có kích thước trung bình nhỏ hơn vạt ngược dòng.

\section{Bảng 3.3: Kết quả sau mổ}

\begin{tabular}{|c|c|c|c|}
\hline Đặc d & liểm & $\begin{array}{c}\text { Sô lượng } \\
\text { (n) }\end{array}$ & $\begin{array}{l}\text { Tỷ lệ } \\
(\%)\end{array}$ \\
\hline Nhiểm khuẩn & Không & 130 & 100 \\
\hline nơi cho vạt & Có & 0 & 0 \\
\hline Nhiềm khuấn & Không & 126 & 96,9 \\
\hline nơi nhận vạt & Có & 4 & 3,1 \\
\hline Chảy máu nơi & Không & 130 & 100 \\
\hline cho vạt & Có & 0 & 0 \\
\hline Chảy máu nơi & Không & 130 & 100 \\
\hline nhận vạt & Có & 0 & 0 \\
\hline & Không & 108 & 83,1 \\
\hline ứ máu tại vạt & Có & 22 & 16,9 \\
\hline & $\begin{array}{l}\text { Vat sống } \\
\text { hoàn toàn }\end{array}$ & 120 & 92,3 \\
\hline $\begin{array}{l}\text { Mức độ sống } \\
\text { của vạt }\end{array}$ & $\begin{array}{c}\text { Vạt hoại tử } \\
<1 / 3\end{array}$ & 10 & 7,7 \\
\hline & $\begin{array}{c}\text { Vạt hoại tư } \\
\geq 1 / 3\end{array}$ & 0 & 0 \\
\hline Liên thương & Nguyên phát & 130 & 100 \\
\hline nơi cho vạt & Thứ phát & 0 & 0 \\
\hline Liên thương & Nguyên phát & 118 & 90,8 \\
\hline nơi nhận vạt & Thứ phát & 12 & 9,2 \\
\hline Tốr & & 130 & 100 \\
\hline
\end{tabular}

Nhật xét: Kết quả khám sau mố cho thây sau mổ tại nơi cho vạt: $100 \%$ không nhiếm khuẩn, không chảy máu, liên thương nguyên phát. Tại nơi nhận vạt: $100 \%$ không chảy máu, 
96,9\% không nhiễm khuẩn, liền thương nguyên phát $90,8 \%$. Tại vạt cho thấy không có hiện tượng ứ máu tại vạt chiếm 83,1\%; 92,3\% vạt sống hoàn toàn.

\section{BÀN LUÂN}

1. Đặc điểm lâm sàng. Kết quả các nghiên cứu của chúng tôi cho thấy VTBT có thể gặp ở bất kỳ độ tuổi nào nhưng tỷ lệ bệnh nhân đang trong độ tuổi lao động, đặc biệt là nhóm người lao động trẻ từ 20-39 tuổi chiểm tỷ lệ cao nhất Kết quả của chúng tôi tương tự kết quả của: Aboulwafa Ahmed and Emara Sherif (2013)[2]. Trong tổng số $116 \mathrm{BN}$ tham gia nghiên cứu BN ít tuổi nhất là 1 tuổi cao nhất là 67 tuổi, độ tuổi trung bình là 26 tuổi. Theo MD Jung Soo Lee và Yeo Hyun (2019) [3]: Tuổi trung bình của 50 BN có VTBT là 47,7 tuổi. Đây là nhóm tuổi có tỷ lệ cao nhất trong dân cư đồng thời là nhóm tuổi đóng vai trò là lực lượng chính trong cơ cấu lao động.

Kết quả nghiên cứu cho thây ngón tay bị tổn thương nhiều nhất là ngón, 2 là với 38 BN sau đó đến ngón 3 là 37 ít gặp nhất ở ngón 5 với $9 \mathrm{BN}$. Kết quả này tương đương với Aboulwafa Ahmed and Emara Sherif (2013)[2] tổn thương KHPM thường gặp nhất là ngón 2,3: trong tổng số 170 búp ngón tay bị tổn thương có 61 búp ngón II, và có 82 búp ngón III, trong khi đó chỉ có 2 búp ngón V. Ngón 2,3 có tỷ lệ tổn thương cao nhất là do khi bị tai nạn theo phản xạ tự nhiên khi bàn tay co ngón cái sẽ được co lại trước để thoát khỏi nguyên nhân nhanh nhất các ngón 2,3 là ngón dài nhất to nhất và, thường sẽ thoát khỏi máy móc, công cụ lao động sau cùng nên dễ bị tai nạn nhất. Ngón 5 vừa nhỏ vừa ngắn vừa ít chức năng nên ít nguy cơ bị tai nạn nhất.

\section{Kêt quả phẫu thuâtt.}

Kích thước vạt che phủ: Kết quả nghiên cứu cho thấy: Vạt ngẫu nhiên có kích thước trung bình nhỏ hơn vạt trục mạch, vạt xuôi dòng có kích thước trung bình nhỏ hơn vạt ngược dòng. Chúng tôi phẫu tích được vat có kích thước lớn nhất là vạt được cấp máu bởi hai nhuồn mạch là nhánh xuyên động mạch gian cốt mu tay thứ nhất và động mạch gan ngón tay chính bờ quay ngón cái vạt có kích thước $3 \times 9$ $\mathrm{cm}$ bao gồm đảo da cân lấy từ khớp liên đốt bàn ngón đến hết mă̆t mu đốt 2 ngón 2 tay phải để tạo hình khuyết hổng toàn bộ chu vi của khớp liên đốt 1,2 và đốt 2 ngón 1 tay phải. Vạt của chúng tôi có kích thước lớn vì chúng tôi đã quyết định giữ lại đồng thời hai nguồn cấp máu cho vạt là nhánh xuyên của động mạch gian cốt mu tay thứ nhất và động mạch gan ngón tay riêng bờ quay ngón 2 vạt có kích thước vạt lên tới $3 \times 9 \mathrm{~cm}$. Phần đầu xa vạt khi đó gần với khớp liên đốt 2,3 ngón 2. Kích thước vạt mạch xuyên lớn nhất của động mạch mu đốt bàn 2 của động mạch gian cốt mu tay theo nghiên cứu của Gebhard $B$ và Meissl G. (1995)[4] là: $6,5 \times 3 \mathrm{~cm}$ phạm vi cấp máu tối đa của vạt này đến mặt mu của khớp liên đốt 1,2 ngón 2. Theo nghiên cứu của Haluk Özcanli và Cs (2015) [5]: Kích thước vạt khoảng: $2 \times 1 \mathrm{~cm}$ đến $2 \times 1.5 \mathrm{~cm}$ đây là vạt mạch xuyên của động mạch gan ngón tay riêng.

Vạt của chúng tôi có kích thước lớn vì chúng tôi sử dụng cùng lức hai cống mạch để cấp máu cho vạt. Nên khi đó phạm vi cấp máu của vạt được tính bằng phạm vi cấp máu của hai vạt thành phần. Sau mổ vạt sống hoàn toàn, không có hiện tượng ứ máu tĩnh mạch tại vạt, vạt và da ghép liền thương kỳ đầu. Theo kết quả nghiên cứu của tác giả Michel Saint-Cyr (2009)[6]: Mỗi vạt mạch xuyên đuộc cấp máu cho một khu vực nhất định gọi là "Perforasomes" vùng cấp máu này có thể đến một nửa lãnh thổ của vạt mạch xuyên liền kề..

Tình trạng chảy máu và nhiễm khuẩn của vạt: Vạt tại chố là một lựa chọn tuyệt vời để tạo hình các KHPM NT. Trong nghiên cứu của chúng tôi với 130 ngón tay được tạo hình bằng vạt tại chỗ không có trường hợp nào phải can thiêp vì tình trang bi chảy máu nơi cho và nơi nhận vạt. Có 4 trường hợp bị nhiễm trùng nơi nhận vạt do nền tổn thương bẩn dập nát sau mổ 3 ngày có hiện tượng chảy dịch mủ tại vạt chúng tôi tiến hành cắt chỉ cách thay băng năn dic vết mổ. Có 2 trường hợp sau 2 lần thay băng vết mồ sạch liền thương nguyên phát. Trong 12 trường hợp liền thương thứ phát nơi nhận vạt có 2 bênh nhân do vạt bi nhiễm khuẩn chúng tồi cắt hết chỉ để vạt liền tự nhiên và $10 \mathrm{BN}$ do vạt bị hoại tử dưới $1 / 3$ diện tích tích. Tất cả các trường hợp này đều được chúng tôi thay băng để liền thương kỳ 2 mà không cần bất kỳ can thiệp bồ xung nào.

Ư máu tĩnh mạch tại vạt: Kết quả nghiên cứu của chúng tôi cho thây có vạt ngược dòng mới xuất hiện tình trạng ứ máu tại vạt, không có vạt di chuyển xuôi dòng nào xuất hiện tình trạng ứ máu. Tất cả 21 vạt di chuyển ngược dòng đều có hiện tượng vạt bị ứ máu thông thường vạt bị ứ máu tím nhe trong trong khoảng 5-7 ngày dài nhất là 10 ngày. Sau gia đoạn ứ máu phần lớn các vạt xuật hiện tái lập tuần hoàn mà không có bất cứ tổn thương gì. Có 6 vạt bị hoại tử mép vat sau giai đoạn ứ máu tất cả các trường hợp đều hoại tử mép và hoại tủ dưới $30 \%$ diện tích. 
Tất cả các vạ hoại tử một phần đều được chúng tôi chăm sóc liền thương tự nhiên.

Theo nghiên cứu của Haluk Özcanli và cs (2014) [7]: Tỉ lệ ứ máu tại vạt mạch xuyên của tác giả gặp 12/15 bệnh nhân tình trạng này thường sẽ giảm dần sau 7 ngày trung bình từ 612 ngày. Tất cả 12 trường hợp này tác giả phẫu tích bộc lộ nâng vạt lên hoàn toàn và chỉ giữ lại các nhánh mạch xuyên của cung búp ngón. Có 3 trường hợp khi phẫu tích giữ lại phần mềm quanh mạch xuyên thì không có hiện tượng ứ máu tĩnh mach sau mổ. Tác giả cho rằng nguyên nhân của của ứ máu tĩnh mạch là do khả năng dẫn máu về của tĩnh mạch tùy hành lúc đầu ít hơn so với nguồn cấp máu của động mạch hoăc do hiện tượng su của tĩnh mạch tùy hành. Mặc dù trong quá trình bóc tách chúng tôi luôn cố gắng giữ lại phần mềm quanh các nhánh xuyên nhưng vẫn có hiện tượng ứ máu tĩnh mạch điều đó cho thấy ứ máu tĩnh mạch là do tổng hòa của rất nhiều nguyên nhân gây nên, trong đó nguyên nhân chính là các tĩnh mạch tùy hành quá nhỏ so với động nên thường không đủ để dẫn lưu máu thoát khỏi vạt, và trong quá trình phẫu thuật không nên khâu vết mổ quá căng sẽ dẫn đến hiện tượng phù nề và ứ máu vạt sau mổ.

Theo nghiên cứu của Haluk Özcanli và cs (2014) [7]: khi sử dụng vạt dạng mạch xuyên sẽ có ưu điểm: Có nguồn cấp máu độc lập chủ động, sức sống vạt cao, không hy sinh mạch chính, khả năng di chuyển của vạt linh hoạt cho phép che phủ các loại KHPM búp ngón tay. Phục hồi tốt cả về chức năng và hình thái BNT. Tuy nhiên nhược điểm : Không chắc chắn sẽ có mạch xuyên, kích thước vạt nhỏ, sẽ có hiện tượng ứ máu tĩnh mạch tạm thời. Kết quả nghiên cứu một lần nữa khẳng định biến chứng ứ máu tạm thời là biến chứng có thể chấp nhận được để đổi lây các ưu điểm của vạt trục mạch và vạt mạch xuyên.

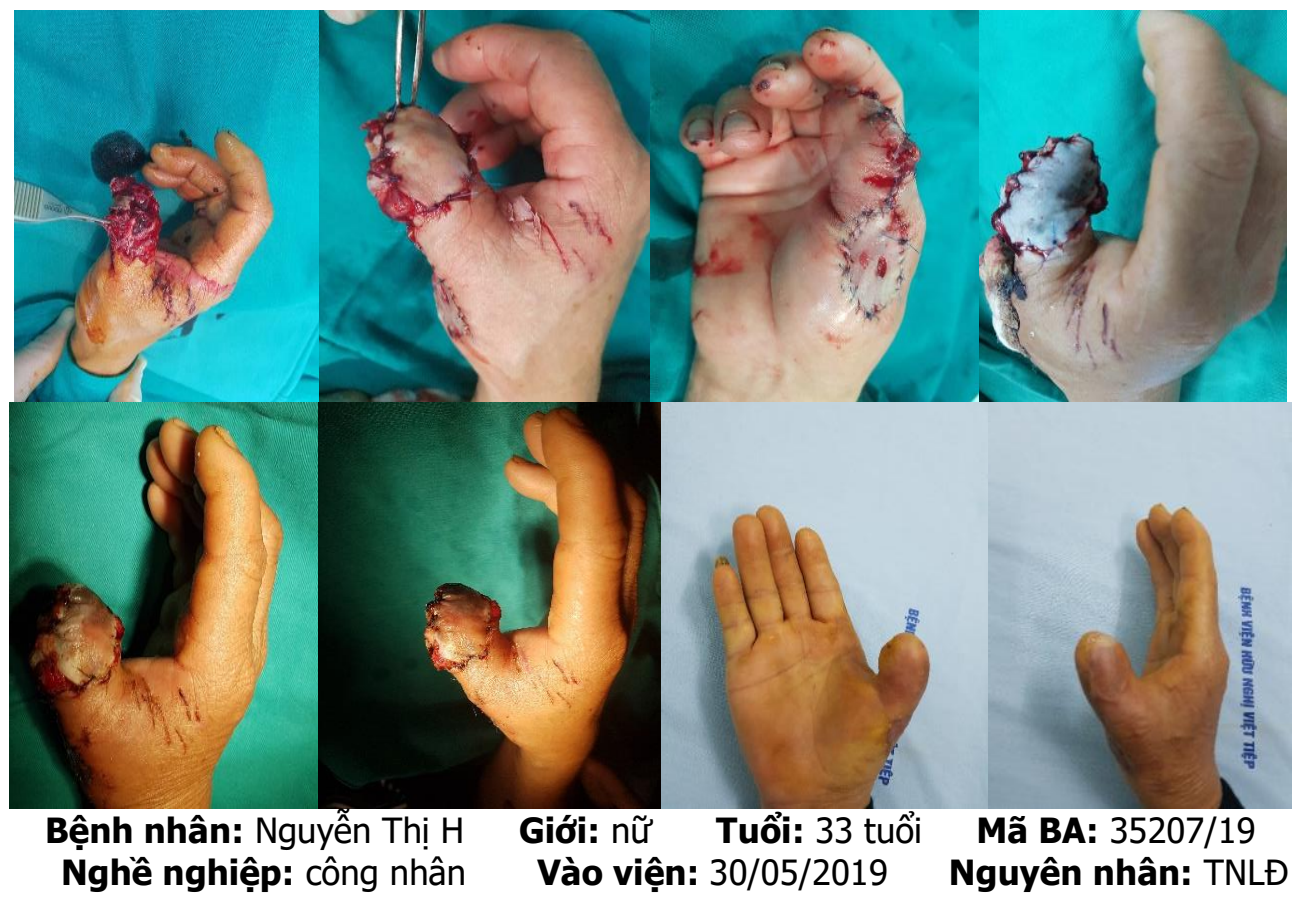

Bệnh nhân bị KHPM mặt mu đốt 1,2 ngón 1 tay phải do TNLĐ, bở vết thương nham nhở dập nát. Bệnh nhân được sử dụng máy siêu âm dopller cầm tay để xác định nhánh mu cổ tay của động mạch quay. Vạt được di chuyển ngược dòng ngồn cấp máu của vạt là các nhánh thuộc vòng nối giữa động mạch mu tay và vòng nối giữa mặt gan và mặt mu vạt có kích thước 4 $x 2,5 \mathrm{~cm}$, nơi cho vạt được ghép da dầy từ nếp lằn bẹn. Sau mổ ngày thứ 2 vạt có hiện tượng ứ máu tĩnh mạch, hiện tượng ứ máu nhiều nhất

ngày thứ 4 sau mổ. Sau mổ 5 ngày hiện tượng ứ máu giảm dần. Kết quả khám lại sau 3 tháng hình thể ngón tay tròn đều, vạt và da ghép bám sống tốt màu sắc tương đồng xung quanh.

\section{Thời gian cắt chỉ.}

Thời gian cắt chỉ của bệnh nhân ngắn nhất là 8 ngày, dài nhất là 15 ngày, trung bình khoảng 10 ngày sau phẫu thuật. Ngón tay được cấp máu rất phong phú nên thời gian liền vết thương ngón tay thường ngắn khoảng 7 ngày. Tuy nhiên chúng tôi thường để khoảng 10 ngày để đảm 
bảo mép vết thương liền chắc không bi toác vết mổ khi va chạm. Các tác giả khác như Aboulwafa Ahmed and Emara Sherif (2013)[2]: trung bình sau 2 tuần bệnh nhân được cắt chỉ, còn theo nghiên cứu của Haluk Özcanli và cs (2014) [7]: BN được cắt chỉ sau 10 -14 ngày.

\section{KẾT LUÂNN}

Qua quá trình nghiên cứu chúng tôi nhận thây: Mỗi loại vạt đều có ưu và nhược điểm riêng: Vạt ngẫu nhiên có ưu điểm kỹ thuật đơn giản, khả năng sống của vạt tốt, nhưng có nhược điểm là vạt có kích thước nhỏ khả năng di chuyển của vạt kém. Vạt trục mạch đặc biệt là vạt trục mạch cuống nuôi ngược dòng có ưu điểm là vạt có kích thước lớn khả năng di chuyển của vạt linh hoạt nhưng có nhược điểm là vạt thường xuyên bị ứ máu tĩnh mạch và mức độ sống không cao. Do đó không có vạt nào là ưu tiên tuyệt đối trong tạo hình KHPM NT, việc lựa chọn vạt áp dụng phải đảm bảo cân bằng giữa mục tiểu tạo hình nơi nhận vạt và ảnh hưởng của nơi cho.

\section{TÀI LIÊU THAM KHẢO}

1. Beasley, R.W. (1983). Principles of soft tissue replacement for the hand. The Journal of Hand Surgery 8(5):781-784.

2. Aboulwafa, A. and S. Emara (2013). Versatility of Homodigital Islandized Lateral $V-Y$ Flap for Reconstruction of Fingertips and Amputation Stumps. Egypt, J. Plast. Reconstr. Surg., Vol. 37, No. 1, January: 89-96, 2013.

3. Jung Soo Lee, M., PhD, Yeo Hyun (2019) Factors associated with limited hand motion after hand trauma. Wolters Kluwer Health, Inc, 98(3):e14183.

4. B, G. and M. G. (1995). An extended frst dorsal metacarpal artery neurovascular island flap. J Hand Surg, 20:529-531.

5. Özcanli, H., et al. (2015). Reconstruction of fngertip defects with digital artery perforator flap. Acta Orthop Traumatol Turc, 49(1):18-22.

6. Michel Saint-Cyr, et al. (2009). The Perforasome Theory: Vascular Anatomy and Clinical Implications. Plast Reconstr Surg, 2009 Nov; 124(5):1529-1544.

7. Özcanli, H., et al. (2015). Reconstruction of fingertip defects with digital artery perforator flap. Acta Orthop Traumatol Turc 49(1):18-22.

\section{ĐẶC ĐIỂM LÂM SÀNG VÀ X-QUANG RĂNG HÀM SỮA CÓ CHỈ ĐỊNH ĐIỀU TRI TUỶ BUỒNG}

Trần Thị Mỹ Hạnh ${ }^{1}$, Nguyễn Hà Thu ${ }^{1}$, Đào Thị Hằng Nga ${ }^{1}$, Nguyễn Vũ Thái Liên ${ }^{2}$

\section{TÓM TẮT}

Mục tiêu: Mô tả đặc điểm lâm sàng và $X$-quang của các răng hàm sũa ở trẻ 3-8 tuổi có chỉ định điều trị tuỷ buồng. Đối tượng và phương pháp nghiên cứu: Nghiên cứu mô tả cắt ngang được thực hiện trên 136 răng hàm sữa có chỉ đinh điều tri tuỷ buồng ở 50 bệnh nhân trẻ em từ 3 đến 8 tuổi, đến khám và điều trị tại Viện Đào tạo Răng Hàm Mặt, Trường Đại học Y Hà Nội năm 2018-2021. Các răng hàm sữa đạt tiêu chuẩn lựa chọn được mô tả các triêu chứng lâm sàng (gồm có: loại răng; vị trí, kích thước lố sâu; tính chất đáy lố sâu), X-quang (giai đoạn tiêu chân răng sữa) và các đặc điểm chung của bệnh nhân (tuổi, giới). Kết quả: Trong 50 bệnh nhân trẻ em được khám và điều trị tuỷ buồng, số trẻ nam ( 28 trẻ, chiếm $56,00 \%$ ) cao gấp 1,27 lần số trẻ nữ (22 trẻ, chiếm $44,00 \%$ ), số trẻ 3-5 tuổi (30 trẻ, chiếm $60,00 \%$ ) gấp 1,5 lần số trẻ 6-8 tuổi (20 trẻ,chiếm 40,00\%). Trong 136 răng có chỉ

${ }^{1}$ Trường Đại hoc Y Hà Nội

${ }^{2}$ Khoa Răng Hàm Mặt, Trường Đại học Kinh Doanh và Công Nghệ

Chịu trách nhiệm chính: Trân Thị Mỹ Hạnh

Email: tranmyhanh@hmu.edu.vn

Ngày nhận bài: 10.5.2021

Ngày phản biên khoa hoc: 28.6.2021

Ngày duyệt bài: 12.7.2021 định điều trị tuỷ buồng, vi trí sâu răng hay găp nhất ở mặt nhai phối hợp mặt bển (60 răng, chiếm 44,12\%), sau đó là măt bên (46 răng, chiếm $33,82 \%$ ), ít găp nhất là mặt nhai (30 răng, chiếm 22,06\%); loại kích thước lỗ sâu hay gặp nhất là trung bình (60 răng, chiếm 44\%); ác chân răng hàm sữa ở giai đoạn I và II. Kết luận: Nghiên cứu cho thấy trong 50 bệnh nhân trẻ em được khám và điều trị tuỷ buống, số trẻ nam nhiều hơn nữ, số trẻ 3-5 tuổi hay gặp hơn trẻ 6-8 tuổi. Các răng hàm sữa có chỉ định điều trị tuỷ buồng thường có lỗ sâu ở vị trí mặt bên phối hợp mặt nhai và kích thước trung bình; chân răng ở giai đoạn I hoặc II.

Tư khóa: Điều trị tuỷ buồng, răng hàm sữa, sâu răng.

\section{SUMMARY}

\section{THE CLINIAL AND RADIOGRAPHIC SYMPTOMS OF PRIMARY MOLARS CHILDREN WITH INDICATION OF PULPOTOMY}

Objective: To assess the clinial and radiographic symptoms of primary molars among 3-8 year-old children with indication of pulpotomy. Materials and Methods: A cross-sectional study among 136 primary molars with indication of pulpotomy of 50 children age group from 3-8 years old, who are taken to School of Odonto-Stomatology, $\mathrm{Ha}$ Noi Medical University in 2019-2021 for dental examination and treatment, 